\title{
IRRIGATION WATER PRICING AND COST RECUPERATION FOR SUSTAINABILITY OF IRRIGATION PROJECTS IN NYANYADZI, ZIMBABWE
}

\author{
Ephraim Chifamba, Takupiwa Nyanga, Simbarashe Gukurume, Researchers \\ Faculty of Social Sciences, Great Zimbabwe University, Zimbabwe \\ E-mail: ephchifamba00@gmail.com
}

\begin{abstract}
Water pricing and recuperation of the costs of irrigation investment have been litigious issues for many decades in the dry area of Nyanyadzi because the community view irrigation as a development expenditure, financed by donors and the government for backward areas through lowering of food prices and reduction of tariffs. The soaring charges for irrigation water are questioned, as well as, the diminutive percentage of farmers who fundamentally recompense the charges. The failure to institute clear cost recuperation and water pricing methods has threatened the viability and sustainability of irrigation projects in the study area. The study used both qualitative and quantitative research methodologies. The study revealed that where the economy is usually subsidized, convalesce the cost of water delivery is much more complicated and difficult. In the case of establishing user fees, these should be estimated as a percentage of the 'traditional user's capability for payment' derived from irrigation benefits (the net increase in farmers' income as a result of irrigation). Nyanyadzi has an opportunity in irrigation led development, if stakeholders address critical challenges in the planning, design, water delivery and maintenance of its irrigation systems. Since Nyanyadzi faces severe budgetary difficulties in financing irrigation projects, it is obligatory to consider the foundation on which irrigation projects operate and impose the principle of self sustaining. Sustainable methods of irrigation evaluation and collection of fees must be considered in light of Nyanyadzi's economic and technical environment. The research noted that water use efficiency is required in order to maximize the benefits farmers derive from the irrigation projects and extraordinarily high user fees should be avoided in the project development stages, where the payment capability is much less at the beginning than at the maturity stages of irrigation projects.
\end{abstract}

\section{KEY WORDS}

Water Cost Recovery; Sustainable Irrigation; Livelihoods; Household Food Security; Zimbabwe.

The past decade has witnessed increased interest in the issue of water pricing as a means for achieving sustainable irrigation management, and for saving a portion of the investments required for the modernization of irrigation systems at the local level. Irrigation led development has been promoted because it holds significant potential to improve productivity, and reduce vulnerability to food insecurity. Despite the fact that there are still difficult technical and economic considerations concerning the subject of water pricing, the issue is still considered highly important in the political and social circles in Zimbabwe (Young and Others, 2002).

Irrigation farming in Nyanyadzi is currently facing a number of challenges. Per capita availability of water is declining rapidly because of a rapid population expansion. The area is moving rapidly into a water paucity and water catastrophe situation. Despite such trends in water availability, Nyanyadzi irrigation projects have been designed, evaluated and operated in a rather narrow sense, leaving aside issues of cost recuperation, water pricing, environmental sustainability, maintenance, and stakeholder participation in decision making. (Young, 1995). Disregard of such issues has resulted in the dwindling of irrigation resources, strained local government finances, and irrational operation of the irrigation systems. The rational for this behavior is a concentration on irrigating more land to meet the rapidly increasing demand for agricultural products, and the subsequent choice for big, not always successful projects. The formulation and implementation of a strategy for water user fees recuperation and clear charging system is of paramount importance for achieving efficiency 
and equity in the use of water and in enhancing social and economic development of the study area (Dinar, 1998). The Zimbabwe National Water Authority needs to review carefully its water related policies and strategies so that water is managed as a social and economic resource with emphasis on conservation. Water related policies may include government decisions about protection of ecosystems, water rights, water charges and water pricing, organizational and social issues.

Furthermore, the cost of water investments are escalating and Operation and Maintenance $(O \& M)$ costs are straining the local budgets. Under such conditions, economic effectiveness is becoming a key objective, and opportunity costs need to guide future water pricing and cost recuperation decisions (Johansson and others, 2002). In this sense pricing for water with the objective of cost recovery becomes a major issue. Furthermore, the role of water pricing and economic incentives for efficient water use is critical in guiding water use and allocation decisions and, hence, the design and selection of appropriate institutional mechanisms (Dinar and Mody, 2004). Its premise is that, given recent trends in water availability, Nyanyadzi irrigation projects should operate under the principle of self-sustaining.

Thus, irrigated agriculture in Nyanyadzi is at a crossroads. Competing demands for water by other users, growing environmental, social, and financial challenges, and lower payoffs for agricultural water investments indicate the need for a change in the way irrigation programs are conceived and designed (Johanansson, and others, 2002). The Nyanyadzi irrigation scheme shows the impact of inefficient use of surface and ground water; cultivation of marginal lands; degradation of soil and water through water-logging, salinity and pollution; inefficient service delivery by public agencies; lack of user access to credit and markets; crop mixes that do not allow appropriate returns to mobilize O\&M fees, let alone investment costs; and selection of inappropriate irrigation technologies. Without urgent prioritization of community participation, addressing operation and maintenance challenges, issues of accountability, transparency and water rights, the consequences is further environmental decay and household food insecurity (Alaerts, 2003)

\section{THE STUDY AREA}

The Nyanyadzi irrigation scheme is situated on the eastern part of the country and the area has a population of over 15000 . Approximately 3700 hectares are under irrigation. Nyanyadzi area is in the agro-ecological region 4, which 250-300 millimeters of yearly rainfall. Nyanyadzi's main habitats are agricultural lands and rangelands. The farming systems are rained, irrigation and mixed crop livestock as defined by Chifamba (2011). Agriculture is based on extensive rearing of cattle and cultivation of rice, beans, maize on irrigated lands and millet on dry lands. However, livelihoods depend on both off and on farm income. Thus, the survival strategies of households depend on both on and off farm income. Thus, the copying strategies of households in Nyanyadzi include diversifying livelihood strategies, intensifying agriculture, exiting agriculture and finding off farm employment during the agricultural off-seasons. Nyanyadzi receives very hostile climatic conditions characterized by high temperatures and variable rainfall. Other challenges in Nyanyadzi include unclear water rights, policy disincentive to invest in dry areas, lack of information about new technologies and farming practices and lack of markets for agricultural products. Hostile climatic conditions have heightened the vulnerability of small scale irrigation farmers to shocks from extreme events. Most surface water originates from sub-soil sources and the Runde River. This implies that any regulations with regard to river water abstraction must include ground water use. The following figure 1 shows the boundaries of Nyanyadzi Catchment. 


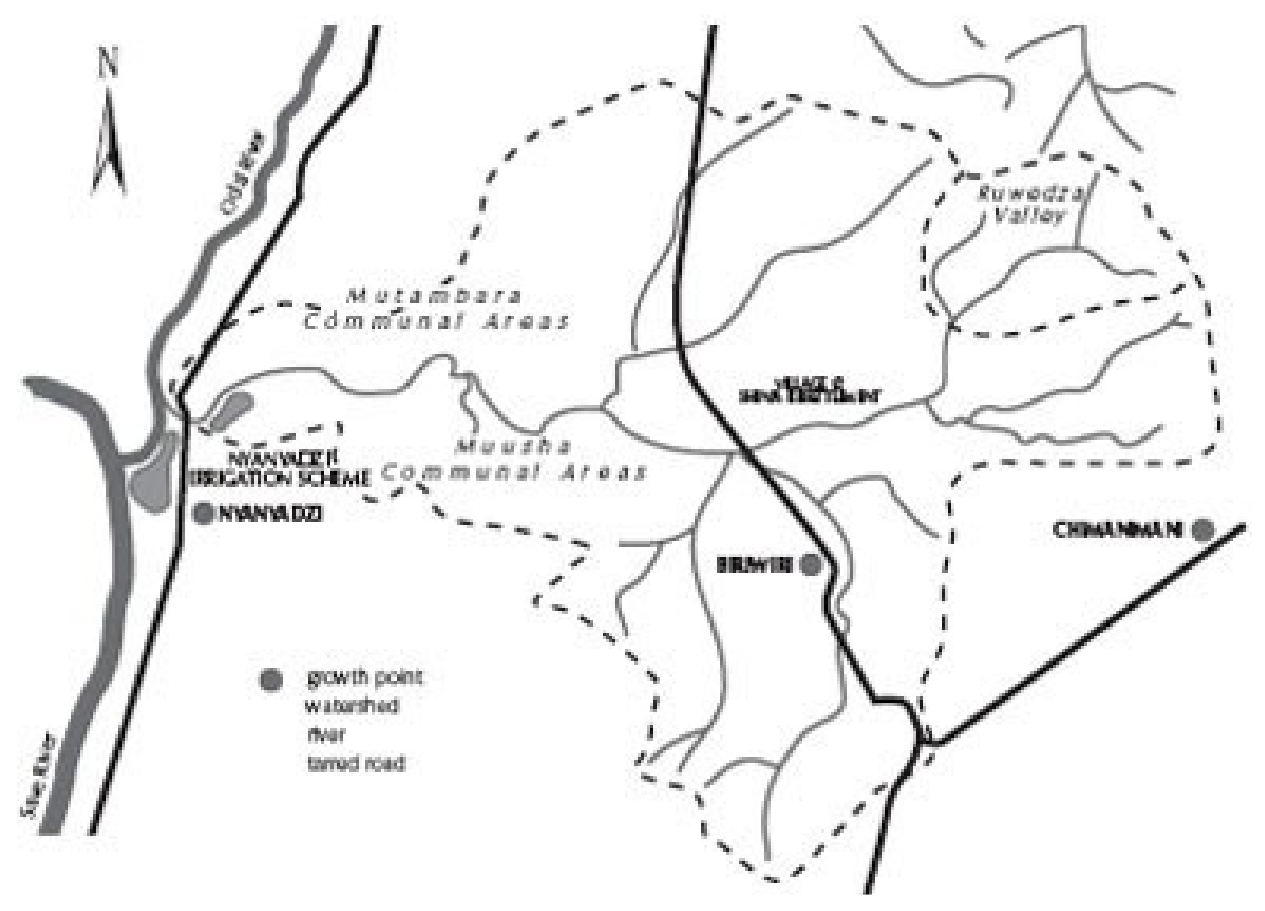

Figure 1. Boundaries of Nyanyadzi Catchment Source: Nyanyadzi Catchment Diary, 2012

\section{STATEMENT OF THE PROBLEM}

Problems of water management in agriculture are gaining increased importance in the dry areas on Nyanyadzi. The implications of a rapidly increasing population on food demand, the environment and water availability are becoming severe. It is estimated that food output has to increase by 40 percent over the next ten years in order to satisfy household food demand and this may come by increasing the productivity of cultivated land by irrigation and increasing output with application of new biological technology (World Bank, 1997). Within this context irrigation water recuperation and water pricing becomes an important factor in livelihood enhancement and household food security. Without adopting proper watershed management to address issues of cost recuperation and irrigation water pricing, the result is further environmental decay and food shortages.

\section{AIMS AND OBJECTIVES}

Aim. The major aim of the study is to assess the implications of irrigation water pricing and cost recuperation on productivity in the dry areas of Nyanyadzi.

Specific objectives. The following objective guide the discussion in this study: assessing the state of irrigation system in Nyanyadzi; establishing emerging challenges in the sustainability of irrigation projects with the overall intensions of scaling up food production and sustain health communities; and generating recommendations which will assist in improving the irrigation system, resolve production bottlenecks and reduce the vulnerability of households to food insecurity

\section{JUSTIFICATION}

The research gathered information on the state of irrigation system in Nyanyadzi, cost recuperation and water pricing methods used in order to find ways of sustaining the irrigation projects in the study area. The study further generated recommendations to stakeholders in irrigation management. The information gathered is important to stakeholders such as government, quasi-government institutions like rural district authorities and Non- 
Governmental Organizations (NGOs). The research will assist stakeholders to see the advantages which can be derived from setting up clear cost recuperation and water pricing methods. If these methods are derived from the contributions of beneficiaries and the local context, participants will comprehend water pricing methods and contribute towards sustainable irrigation in the area. In the long run the research will contribute towards effective management of irrigation water, thereby increasing water productivity. These institutions will find the information important since it will also give options available for sustainable cost recuperation, effective water pricing methods, food security, social and economic development, and sustainable agricultural growth,

\section{CONCEPTUAL FRAMEWORK}

Irrigation water pricing is often focused directly on two issues of financial sustainability of irrigation systems, and the problem of excessive water consumption (Jones, 1995). The correlation between the cost of goods and its market value is well known in economics. Water is no exception to this law, and yet it may become invalid under two conditions: If the price of water becomes too high or if water is sold on a unit quantity basis. However, those two conditions are the exception rather than the rule. In most cases irrigation rates do not generally have any impact on irrigation efficiencies. Thus, if the farmer suffers from water shortage, he will try to use whatever quantity he can obtain by any means available to him. Therefore, it does not seem reasonable to set a pricing policy for water by attempting to force him to use it efficiently.

Concerning the measurement of water quantity as a basis for water pricing it has been found that the cost of installation, operation and maintenance of the measuring devices themselves (counters or other) are sometimes rather high, which in turn increases the price of water ( Postel, 1999). In most cases, the cost of water represent $10-20 \%$ of the production costs for the majority of crops and as for the vegetable crops, for instance they may be as low as $5 \%$ (Schur, 1999). Thus, one might expect that water pricing would have a great effect on the farmer's preference for certain crops over others. In order that such costs would have a tangible impact on the production, they should be increased a trend which is now favored in countries such as South Africa, Egypt and Ghana ( Howe, 1979). In such a case, the farmer will find ways to avoid cultivating the high water-consuming crops.

Since irrigation water pricing and cost recuperation are fundamental basis for ensuring proper operation and maintenance of irrigation equipment, it is important to review and adjust all operation and maintenance practice before considering a policy (Tsur, 2000). This should take place in the framework of acceptable management concepts, which is different from one country to another according to their different social and economic conditions. Other alternatives for lowering the operation and maintenance costs are to transfer some of the responsibilities to the water users themselves, or to design and operate the networks in such a way as to ensure their high efficiency and cost-effectiveness ( Ben-Abdelrazzik, 2000). All this should take place within the environment of a very efficient management system. In the case of assigning the management of part of the irrigation network to the farmers, the costs of operation and maintenance may probably be greatly reduced. An additional advantage is the farmers' feeling of commitment due to their participation in operation and maintenance. The farmers' responsibility of managing part of the network necessitates the precise determination of their duties and rights. According to Coward (1980) a worthwhile consideration is to have them participate in decision-making, valuation and collection of fees, and scheduling the required training and organizational assistance for their service. Official instructions and clear procedures may be necessary to regulate such matters.

In the design of different irrigation projects it has been observed that the improvement and modernization process of irrigation networks have noticeably increased within the last twenty years without consideration of the factors that reduce operation and maintenance costs (Tsur and Dinar, 1997). Consequently, many projects now represent a heavy financial burden on stakeholders, especially poor farmers, without finding practical solutions for the problem. Therefore, it is importance to give more attention during the design stages of these 
projects to reducing their operation and maintenance costs to a minimum and devise cost recovery methods which do not further burden stakeholders

For sustainability of irrigation projects fee structures have to be equitable, administratively simple, and easily understood by users and those administrating the fee collection. Part of this involves identifying the full range of services and benefits produced by the project and allocating project costs among all beneficiaries ( Gleick, 1997). In addition, information on the costs of services and benefits derived from the project and on the way project costs are allocated among beneficiaries should be provided to all users. For a new project or any major improvement in infrastructure, users' ability and willingness to pay should be assessed.

\section{IRRIGATION SCHEMES AND COST-RECOVERY PRINCIPLES}

Improving cost recovery clearly involves more than just charging higher fees or spending more on fee collection. The full costs of providing irrigation water can be divided into three categories: direct project costs, environmental costs, and marginal user costs (Johanansson and others, 2002). Direct project costs are the easiest of the three to measure, and most projects take only direct costs into account in determining cost recovery. Direct costs refer to costs stemming from the process of capturing and delivering irrigation water, which can be broken into fixed costs and variable costs (Howe, 1997; Dinar, 1994). Fixed costs include all investments in irrigation infrastructures such as building reservoirs and canals and installing meters and pumps, plus depreciation and interest payment on the investment. Higher level administrative costs and some operational and maintenance costs not involved with actual water delivery are also considered fixed costs because they do not vary with the amount of water delivered. Variable costs consist of the operational and maintenance costs of water delivery, lower level administrative costs (usually temporary labor costs during the time of water delivery), and costs of supplying water, which include conveyance costs, groundwater extraction costs, and costs due to water loss (Maars and Anderson, 1978). These costs vary with location, water delivery method, irrigation technology, and season.

Environmental costs include soil erosion and damage to the surrounding ecosystem during and after the construction of an irrigation project as well as water logging and salinity problems caused by the irrigation. However, few irrigation projects in practice include environmental costs as part of their full cost to be recovered. Environmental costs can substantially raise the total costs of many irrigation projects (Bosworth and others, 2002). After determining which of these costs to include, the next concern is what percentage of total costs should be allocated to farmers. In many cases, who should bear the costs of providing irrigation water is not clear. Whether the farmers should pay the full costs depends on factors including project objectives and the number of beneficiary groups. Irrigation projects serve multiple beneficiaries in two major ways. One case is multipurpose projects; the other is projects involving indirect beneficiaries of the increased agricultural production. Multipurpose water projects are common. Besides supplying irrigation water, projects may also supply water for household and industrial uses as well as providing flood control and hydropower. In Asia, 90 percent of dams for irrigation are multipurpose. In these cases, different users should share the costs in proportion to the services they receive (Berbel and Gomez-Limon 2008).

There are three common methods for allocating costs among users: the use of facilities (UOF), alternative justifiable expenditures (AJE) and Separate Costs, Remaining Benefits (SCRB) methods (Gleick, 1992: Leinos and Olivera 2004; Jones 1994)). The first approach, UOF, allocates costs among different types of users sharing the same facility in proportion to the water delivered to each type of user (such as irrigation and domestic water supply). The second approach, AJE, allocates joint costs based on remaining benefits after subtracting specific costs, where specific costs refer to costs directly attributable to a single purpose and exclude the costs of a change in project design due to the inclusion of a particular purpose ( Tsur and Dinar, 1998). AJE is easier to calculate than SCRB because it relies on specific 
costs rather than separable costs. The third approach, SCRB, is similar to the second one. It assigns costs that serve a single purpose to the benefiting purpose, including the costs of any project design changes required to include the added purpose. The remaining "joint" costs are assigned in proportion to the remaining benefits derived for each type of use after subtracting the separable costs. An irrigation project in Egypt, on the banks of the Nile River provides a good example of how the costs from a multipurpose water project can be allocated among different types of uses or purposes (Easter, 1993). In projects with large indirect benefits, some of the costs may be allocated to the beneficiaries. For example, in South Africa where the government pursues a low food price policy, food processors and consumers both may benefit more from irrigation improvement projects than farmers. In such cases, subsidizing the project through tax revenue from the benefiting consumers and processors might be an alternative to help fund the project.

\section{PRICING SCHEME DESIGN}

To achieve the two primary goals of cost recovery and reduced water use per unit of output in irrigation water management, two key issues must be addressed: firstly there is need to design an effective pricing mechanism based on local conditions and, secondly there is also need, to develop a strategy for obtaining high rates of collection. There are three major methods for water pricing namely area-based pricing, volumetric pricing, and market equilibrium pricing.

Area-Based Pricing. Area-based water charges are fixed charges, based on the area irrigated or supposed to be irrigated. Area based pricing is calculated by dividing the total area irrigated into the operation and maintenance costs of providing irrigation water, which basically follows the average cost pricing principle (Prato, 1998). Defining O\&M costs is important because the water supply entity may have an incentive to inflate the costs charged to farmers. In addition, the use of irrigated area varies from year to year and season to season. For example, the area irrigated during the wet season is usually much larger than during the dry season.

In addition, the project area is usually larger than the area actually irrigated. Therefore, irrigation officials will need to estimate the area actually irrigated each season. The disadvantage of this pricing method is that, once the irrigated area decision is made, the water charge will have no effect on farmers' water consumption, because the marginal cost of applying additional quantities of water per hectare is zero (Tsur and Dinar, 1998). Thus, the demand for water is usually higher than it would be under a price or charge that varied by the quantity of water used, and it is likely to lead to overuse of water by farmers near the head of the canal. The advantage is that it is simple to calculate, easy for farmers to understand, and the implementation costs are lower than for volumetric pricing because water deliveries do not have to be measured (Nark and Kalro, 2000).

Also, assuming 100 percent collection rates, charges per hectare, based on average direct cost; result in full recovery of direct costs ( Tsur and Dinar, 1998). Although it gives farmers no incentive to reduce water use per hectare, it is still widely used in many systems throughout the world due to the simplicity of its implementation. Area-based pricing is appropriate in places where water is not scarce, where crops are not varied, and where meter installation is difficult or costly. However, area-based pricing systems are becoming less and less popular, and most of the recently designed area-based pricing systems are adopting new features. The extensions of area pricing include area-crop (the most widely used modification), area-irrigation, area-season, and area-technology-based pricing (Tsur and Dinar, 1997).

Area-crop-based pricing. Area-crop-based pricing vary the charge per hectare irrigated by type of crop. The water price variation among crops depends on the policymakers' objectives. If they want to encourage efficient use of water, the high waterconsuming crops such as rice, should have higher prices per hectare. If the price differences are large enough, farmers are likely to switch to alternative crops. In contrast, if the government is pursuing a low food price policy or wants to encourage production of commercial crops, the water price for these crops could be set lower than for other crops. 
However, care must be taken in subsidizing inputs such as water to increase crop production because it often leads to inefficiencies and overuse of the resource, particularly with crops such as rice and sugarcane (Tsur, 2000; Cakmak, 2000; Zhang, 2002).

Area-Season-Based Charges. Some countries use area -season-crop based pricing system, for example, a higher price is charged during the dry season, when water is scarce, and a lower price is levied in the monsoon or wet season, when water is relatively plentiful. If the price is set high enough in the dry season, it will help limit the number of hectares irrigated in that season. In Egypt, the pricing structure was based on different costs for offpeak and peak water use. The peak season lasts five months in the summer, and the water price reflects the long-run marginal cost of supplying water. The long-run marginal cost is usually the cost of future expansion. In reality, it is often difficult to estimate the cost of the next big supply-capacity-expansion project (World Bank, 1995). During the off-peak seasons, France includes only operating costs. This pricing structure has assisted in reduce water use during summer when demand is high compared to supply (Tiwari and Dinar 2003; Johansson et al. 2002).

Area-Technology-Based Pricing. The basic idea in area-technology based pricing similar to area-crop-based charges, with farmers using water-saving technology paying lower per hectare water charges. For example, drip and sprinkler irrigation generally allow better water control and more output per unit of water delivered than flood irrigation. Therefore, a higher per hectare fee could be levied on farmers not using these technologies to encourage them to switch to water saving technologies. If area-based charges can be established that reflect differences in water use by season, crop, or irrigation technology, area pricing would have some of the benefits of volumetric pricing ( Schur, 1999). Problems are still likely to exist because farmers at the head of the canal tend to over irrigate their fields when water charges are based on area. However, if farmers can be assured that each scheduled water delivery will be on time and in the quantity demanded, they will have much less incentive to over irrigate than with irregular deliveries.

\section{VOLUMETRIC PRICING}

With volumetric water pricing, the charge is based on the amount of water delivered. The economic optimal pricing rule requires that price should be set equal to the marginal cost of providing the water, and it requires accurate measurement of water through meters (World Bank, 1995). The advantage of this pricing method is that it encourages farmers to limit their water use. Also, it is easy to understand in the sense that farmers pay for the quantity of water delivered to their irrigated plots. However, it has several disadvantages. First, the implementation costs can be high because meters are required, and they have to be honestly read and reported. Second, marginal cost pricing does not allow full cost recovery in the case of decreasing average costs. Once the infrastructure is in place, the marginal project costs will be lower than average costs, thus pricing based on the marginal cost will not achieve full cost recovery. In contrast, for the case of pump irrigation using groundwater, the marginal project costs are likely to be higher than average project costs, particularly when marginal costs include the marginal user cost. Thus, for some groundwater projects, marginal cost pricing could result in over collection as well as high water charges relative to farm income. To address the concerns about the impacts of water charges on farm income, two different modified versions of volumetric pricing namely block pricing and two -part tariffs can be used.

Block pricing. Block pricing involves varying the water price when water use for a set time period exceeds a set volume for example $4,500 \mathrm{~m}^{3}$ per hectare per season). If high water charges are a concern, an increasing block charge can be used. The price of the first block can be set below operation and maintenance costs. The second and later blocks are raised to higher rates that cover operation and maintenance costs and reflect the marginal cost of operations. Egypt (Dinar, 1994) and Tunisia (Jones, 1995) both use this pricing method. The amount of the first block is often considered the basic amount of water needed to support a farm family, so this method also attempts to address equity issues. Farmers pay a low rate for the first block but a much higher price for any water used that exceeds the first 
block. In Brazil, for instance, the price of the second block is twice the price of the first block (Coward, 1980). This pricing method operates similarly to a quota. In fact, a quota is an extreme case of increasing block pricing. Even when an official quota exists, farmers can still obtain additional water by paying irrigation officials or private sources a high enough price.

If the price difference between blocks is large enough, farmers try not to use more than the allocated block of water. The disadvantage of block pricing is that it is not easy to decide the price level for each block or the quantity range of each block. In addition, the revenue is unlikely to cover the O\&M costs, particularly if the range for the allocated block of water is large. It is appropriate to use in cases where water is scarce, farm incomes are low, and water charges are high relative to net farm income. The advantage of the two-block pricing is that you have, at least, three instruments for influencing water use and cost recovery: the first and second block prices and the quantity (e.g., 4,000m3/ha. vs. 5,000m3/ha.) at which to start the second block price ( Tsur and Dinar, 1998).

Two-part tariff. The second modification is a two-part charge, which is a combination of volumetric pricing and a fixed admission charge (sometimes based on size of the area irrigated). For the block pricing methods described above, the two objectives - full cost recovery and reduced water use - are often in conflict. The advantage of a two-part charge is that it can reconcile the conflict. The volumetric part can be based on marginal cost, which encourages less water use, while the fixed part can be used to make up any deficits and ensure a certain revenue flow regardless of how much water is available and delivered. Even for O\&M costs, there is a fixed component that does not depend on the amount of water delivered, and these fixed costs have to be paid even when water is not used for one season. The disadvantage is that it is relatively hard to calculate and difficult for farmers to understand. In addition, the administrative costs of a block-pricing scheme are likely to be somewhat higher than a single charge scheme.

\section{RESEARCH METHODOLOGIES}

The research rests fundamentally on a survey conducted amongst irrigation farmers and water supply organizations to assess water pricing and cost recovery for sustainability of irrigation projects in Nyanyadzi. Contingent Valuation (CV) was used to evaluate the factors which affect the viability of irrigation schemes in Nyanyadzi. For collecting primary data, the questionnaire was first pre-tested to evaluate its effectiveness. Feedback from the pre-test was used to revise the questionnaire. The interviews were conducted between months of August to November 2012. Enumerators involved in this research underwent a two days training workshop and were introduced to econometric models. The econometric software STATA was used to analyze the data.

\section{RESEARCH FINDINGS}

Age-Sex. The research gathered information from both sexes but females constituted the majority compared to their male counterparts (66\% as compared to $34 \%$ ). Their ages ranged from slightly below 30 years to 60 years. This showed the ages of respondents were still economically active and no respondent was in the retirement age or minor. The $51-60$ years age group was the largest that constituted $36 \%$ and the $31-40$ years age group was the second largest constituting 28\%. The $41-50$ years age group and 30 years and below constituted $23 \%$ and $19 \%$ respectively. Those whose ages were below 30 years had ages ranging from 26-29 years. Table 1 shows the age-sex profile of respondents.

Table 1. Age-Sex Profile of Respondents

\begin{tabular}{|c|c|c|}
\hline Age Group & Males & Females \\
\hline $25-30$ & 8 & 11 \\
\hline $31-40$ & 5 & 23 \\
\hline $41-50$ & 7 & 16 \\
\hline $51-60$ & 14 & 14 \\
\hline Total & 34 & 66 \\
\hline
\end{tabular}

Source: Survey, 2009 
Academic Qualification of Respondents. Respondents were of varying background. It included those who had no formal education, those with elementary education, to holders of tertiary education. The respondents showed that a number of them had acquired meaningful education, as $86 \%$ of them had at least Zimbabwe junior certificate level of education; of this $49 \%$ had at least attained ordinary level. Only a few had no formal education (14\%) which shows that the majority of respondents were literate and therefore could read and write. These people can be trained to run projects effectively if the program is planned well. Some of them who had tertiary education could be trained to take positions of responsibility so that they can lead the project. TBNRM initiatives should appreciate that communities are better placed to manage resources around them and communities can cooperate where the realize benefits accruing to them.

Marital Status of Respondents. Respondents were drawn from varied marital status, which ranged from married, widowed, divorced and singles. The majority of them were married (48\%) and the singled constituted a significant percentage (27\%), of which males were the majority (20\%). The widowed and divorcees constituted a combined $25 \%(13 \%$ and $12 \%$ respectively). Figure 2 shows the marital status of respondents.

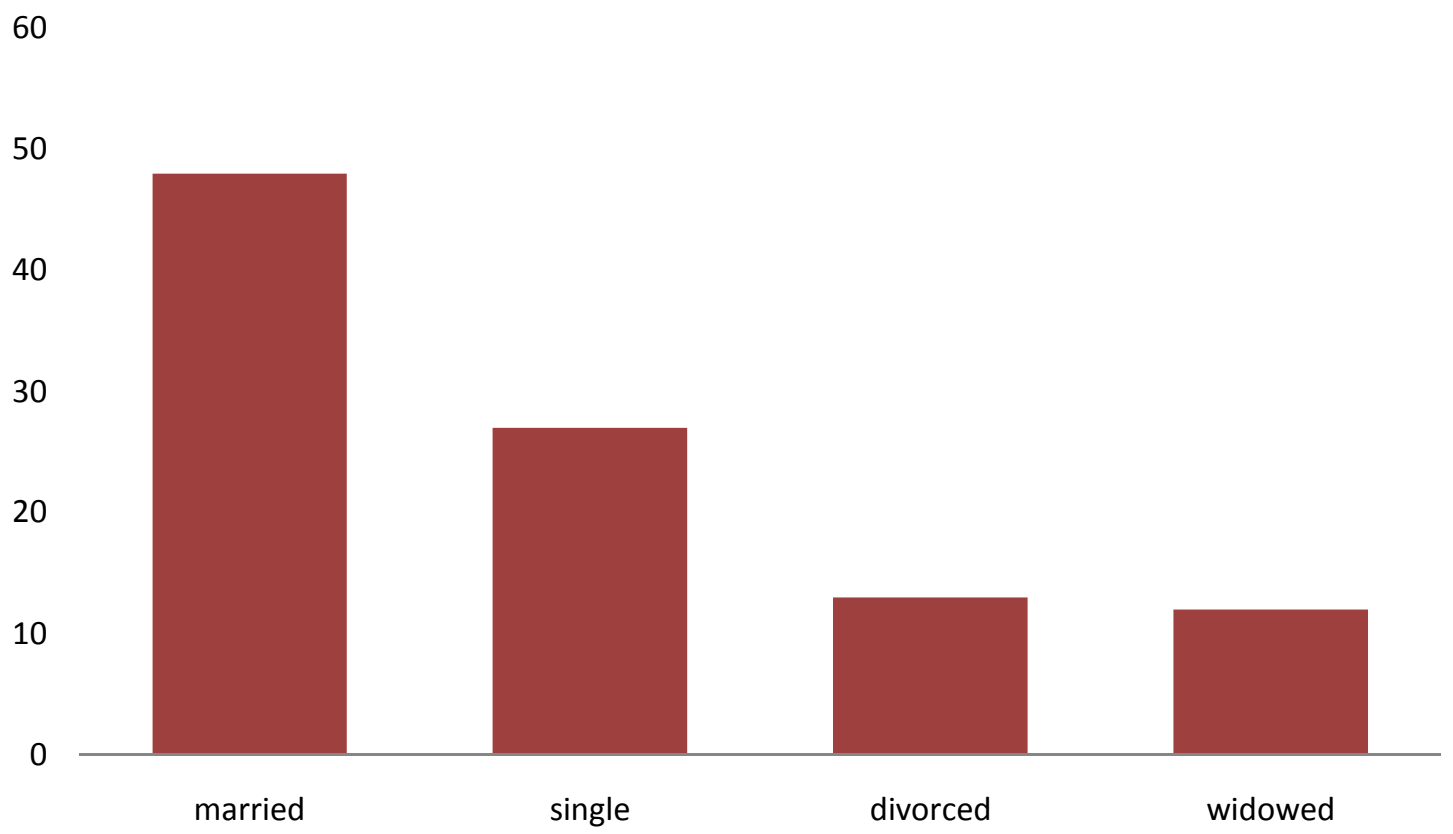

Figure 2. Marital Status of Respondents Source: Survey, 2009

\section{AN OVERVIEW OF THE MANAGEMENT OF NYANYADZI IRRIGATION SCHEMES}

In Nyanyadzi, irrigation water management is primarily the responsibility of organizations set up at the prefecture and local level, according to the principles of cooperation, integrated leadership, grade-level management, and professional and massive management. The district irrigation division, which is managed by the prefecture bureau, is responsible for managing key projects in the area; planning irrigation water use and water distribution; and instructing the work of the irrigation sub-sectors. The functions of irrigation agency operating at the local level are similar to those working at a higher level. The executive committee of the irrigation scheme is comprised of leaders from different sectors of local government and traditional system. The director of the irrigation committee is the vice director of the prefecture's authority in charge of water management. The vice directors are the directors and vice general secretary of the general office and the chief of the prefecture's irrigation division. The management is chosen amongst leaders of several administrative 
sectors and the stakeholders benefiting from the irrigation project. The executive committee is in charge of supervising the irrigation scheme, representing the grassroots masses, determining the development and reform strategies for the irrigation districts. The grass root managerial groups are responsible for organizing the farmers who live along the canals, managing the construction of dikes and auxiliary works. Irrigation bureaus define plans for water use, estimate volumetric water supply, and assess water distribution according to the principle of grade-level management.

Until 1982, water fees were managed as administrative fees through fiscal department of governments (Chifamba, 2011). During the period from 1990 to 1997, water fees were increased annually by $\$ 40.00$ ( Gleick, 1997). Currently water fee standards are determined on the basis of water supply costs. Water fees vary between upstream and downstream canals. The prices also vary according to the different irrigation seasons. Before the peak irrigation season, water fees are discounted. If water demand exceeds the planned quotas, water fees are determined on the basis of a block tariff. Water fees are collected by and accounted for at various management levels. Proposals from the prefecture and county level related to water fee adjustment should be reported to the prefecture government and the farmer burden-reduction office. Once their proposal is accepted, irrigation organizations must give farmers a notice, known as the farmers bearing production fee receipt. Farmers pay their water fees to the township financial department, which submits all water fees to county financial departments. The financial departments later redistribute 60 percent of the water fees back to the prefectures and keep the remaining 40 percent. The prefectures' irrigation divisions reward counties who submit their water fees on time by granting them an extra 11.5 percent of water fees or by sometimes granting them additional funds for water conservancy projects.

\section{FACTORS FOR SUSTAINABILITY OF IRRIGATION PROJECTS IN NYANYADZI}

Irrigation Water Conservation and Water Conservation. In light of water scarcity, there is need to conservation irrigation water and use water pricing and other mechanisms to reduce water use per hectare. When water metering is not possible, area-crop and areatechnology based water charges should be designed to strengthen farmers' incentive to shift to crops that need less water or to shift to water-saving technologies, or both. This works only if alternative crops and technologies are available and can be adopted without a significant drop in net farm income. Where feasible, water markets should be encouraged as a means of improving water allocation as well as water conservation. One clear advantage of water markets is the flexibility they provide for moving water to higher valued uses while, in most cases, leaving both buyers and sellers better off. A number of countries, such as Chile, the U.S. West, Spain, and Australia have made effective use of water markets, with positive outcome (World Bank, 1997).

Public awareness, education, and training programs should be used in water-scarce regions to make farmers fully aware of the economic value of water and the need to use it judiciously. This has been done in a number of projects including the ones in Awati (China), Katepara (India), Yangtze (China), and Egypt (Dinar, 1994). In other words, users need to understand the importance of conserving water. Farmers will also need training and technical assistance to switch to better irrigation cropping practices and technologies. Special training programs will be needed before the irrigation water is made available where irrigation is being introduced for the first time.

There are two key steps in cost recovery in Nyanyadzi irrigation schemes: the first is to design a pricing mechanism that covers the appropriate costs; the second is to achieve high collection rates through effective water management. The design involves working with Zimbabwe National Water Authority (ZINWA) and farmers to determine what should be included in the costs, and which of these costs should be collected through a water fee rather than through other taxes such as a land tax or a local property tax. Once this decision is made, setting the appropriate fee level becomes an accounting problem influenced by the type of irrigation system and ability to measure and monitor water use. When the volume of 
water delivered cannot be measured, water charges are usually based on some measure of area irrigated. Sometimes the area-based charges are adjusted to account for crops grown and season of the year. Even if the appropriate water charge is determined, the more difficult step still remains: achieving high collection rates.

A key to achieving high collection rates in Nyanyadzi hinges on financial autonomy. Without autonomy, collecting sufficient funds from users does not guarantee improved O\&M services because revenues from water charges, in many cases, do not go back to the project. Instead, they are commingled with other taxes in the central treasury, as in India. This probably explains why Jones (1995) found that, in many projects, there is no direct relation between water charges and the service quality. Shifting irrigation project management to a financially autonomous organization-it does not matter whether it is a government agency, a local water user organization, or a private entity-will create a financial incentive for improving irrigation services. Better services will give farmers an incentive to pay their fees as well as an increased ability to pay because better service usually means higher farm incomes. Financial autonomy can be an important key to improved irrigation water management by providing a positive feedback system through a direct financial link between farmers and the water suppliers (Young, 1985).

Financial autonomy ensures that revenue from water charges will revert to the project. Service providers no longer receive subsidies from the central government, which means they have to collect water fees from users to recover their costs. In such cases, they are likely to create incentives to achieve high fee collection rates. Some suppliers strictly enforce penalties against payment defaulters. In Bayi Irrigation District, China, payment defaulters' irrigation water is cut off until they pay their debts (Johnson and others, 1996). In Shangdong, China, the use of integrated circuit (IC) machines insures that farmers cannot obtain irrigation water without paying. Farmers must purchase a prepaid IC card to operate the IC machine that measures and controls the water release (Zhang and others, 2003). These are practical examples of best practices which can also be implemented in the study area. In this case, although financial autonomy is not mentioned, using IC machines is an innovative way to collect charges, which gives farmers full control over water use and also effectively enforces payment collection. This system reduced water use per hectare and achieved 100 percent collection rates at the same time.

\section{COST SAVING THROUGH REDUCING WATER USE}

To encourage farmers to use less irrigation water per hectare, water charges have to be related to the amount of water that farmers receive. Thus, volumetric water pricing should be considered when reducing water use per hectare is the major concern. In cases of high volumetric measurement costs, area-crop or area-technology based pricing methods can be considered as a second best approach if they can be designed to influence water use, as discussed above (Tsur and Dinar, 1998). There are two general approaches to reducing water demand through pricing. One is to set the per unit price high enough so that farmers use less water on existing crops, which is essentially a movement along the negatively sloping demand curve. The second approach is to shift the entire demand curve by inducing farmers to change crops or irrigation technology, or both.

A number of studies of individual crops suggest that irrigation water demand is quite inelastic. In Tunisia, the price elasticity of water demand was estimated to range from -0.03 in the Northeast and -0.007 in the Center-West to -0.27 in the Northwest and -0.34 in the South (Young and others, 1982). The two former areas that have very inelastic water demands produce high-value crops under controlled water conditions (fruit trees, vegetables, plastic-covered agriculture irrigated with modern technologies) (Cackmak, 2000). In such cases, water prices have to increase substantially before they will significantly reduce water demand. In the process, farmers' income will be adversely affected. In parts of Spain, some estimates suggest that farmers' incomes would need to fall by 25 to 40 percent before an increase in the price of water would lead to significantly lower water consumption (Berbel and 
Gomez-Limon, 2000). In a case in Iran, water prices would have to be raised from $\$ 4 / 1,000 \mathrm{~m} 3$ to $\$ 20 / 1,000 \mathrm{~m} 3$ to significantly reduce demand (Perry 2001).

Such a large increase in the price of water may not be politically acceptable. In addition, farmers must have alternative choices to be able to reduce water use per hectare. Therefore, an increase in per unit water price may not be an effective way to reduce demand if alternative crops and technologies are not readily available and water price elasticity of demand are low. Yet, Dinar (2004) found own-price elasticity of agricultural water demand ranging from -0.275 to -0.415 in California's San Joaquin Valley. They found the indirect effects to account for only 17 percent of the change in water use. In other words, just reducing water use on the existing crops was more important than changing to waterconserving crops or to improved technology. Their study suggests that movements along the demand curve result in significant water savings. Thus, whether a water price increase will significantly reduce demand has to be determined and then, if it does, whether it is due to a movement along the demand curve or a shift in the demand curve. In cases of very inelastic demand, policies and practices that shift the demand curve to reduce water use should be used.

Supporting institutions. To shift the demand, alternative choices of crops or technology have to be available. A shift to a less water-consuming crop or to a water-saving technology can move farmers to a significantly lower level of water use. If there is a wide variety of crops to choose from, policymakers can use either area-crop-based pricing or increase the per unit volumetric price to induce a shift to crops that use less water. The same strategy can be applied to an irrigation technology shift. The pricing mechanism can be either volumetric or area-technology based. The price increase will be even more effective if combined with other policy interventions such as providing positive supports or taking back subsidies that encourage lavish water use. Low-interest loans for new equipment and technical assistance will help encourage farmers to adopt appropriate water-saving technology. In Gujarat, India, electricity used by tube wells is charged at a fixed rate per month and is heavily subsidized (Easter, 1993). Therefore, electricity charges do not include any charge for the marginal cost of pumping groundwater. In this case, the government should eliminate the electricity subsidies, which have been encouraging overuse of groundwater, and charge for electricity based on the amount of electricity used. The resulting increase in pumping costs would encourage farmers to use less groundwater per hectare and save more for future use. However, under certain conditions, with high enough electricity prices, farmers may move from electricity-operated pumps to diesel-operated pumps (Dinar 1994).

Quotas. Besides using pricing tools, there are several other means to reduce water demand. One is to use a water quota. A quota system is generally used to define the quantity of water that can be used in a given time period, by whom, and for what purpose (Naik and Kalro, 2000). When water users are not responsive to water price changes, a quota can be effective in reducing water consumption by creating a high shadow price. The implementation costs of quota systems can be high because the quantity of water that goes to each farm must be controlled. There are different ways of implementing a quota system. First would be a fixed quota system for groundwater pumping with a specified annual rate of extraction in proportion to the land area of each water user.

A second approach would be a fixed allocation of water shares to different canals and water users sharing water from the same canal. The fixed shares or quotas could also be allocated to WUAs (Dinar and Mody 2004). For example, in Maharastra, India, the WUA receives $0.77,0.86$, and 0.62 million cubic meters of water during winter, dry, and summer seasons, respectively. They can also draw on any unused water quota from the previous season in the current season (Naik and Karlo 1998).

Service Contracts. Another way of reducing water use per hectare is to provide assurance that water will be delivered on time and in the amount demanded. If this is done, farmers will not have an incentive to store water on their field by over irrigating. Since system reform in Katepurna, India, for example, farmers no longer flood their fields in the dry season and often do not irrigate in the monsoon season because irrigation scheduling is planned 
ahead according to water requirements and soil type (Jones, 1995). Farmers no longer have to irrigate in the monsoon season just so that they will have adequate soil moisture for the dry season crop. Farmers now have an adequate and timely water supply, resulting in reduced water use per hectare. Not only are they saving 7.7 million m3 annually, but they also expanded the irrigated area from 2,027 to 3,646 ha, an 80 percent expansion. This case shows a real increase in productivity (Alaerts, 2003).

Education. A third effective mechanism for reducing water use can be public education campaigns to make farmers aware of water scarcity and convince them it should be treated like an economic commodity. This is especially important in places where people traditionally view water as a free good and a basic right. In many projects, public education programs, combined with price increases, have been effective. In Brazil, the formation of a WUA and the need for efficient water utilization were promoted through newspapers, radio, exhibitions, pamphlets, and posters. Slogans on participatory irrigation management and efficient water use were written on compound walls, canal structures, offices, and public buildings (Young, 1985). To motivate irrigators, cultural groups were formed from department staff members and cultural programs (e.g., songs, drama) were arranged at the village level (Dinar, 1994). This helped motivate irrigators by improving the community understands of the value and importance of irrigation water. Nyanyadzi can still adopt this system because it is not expensive and it has the potential to disseminate information faster.

Incentives. Incentives can also be used to induce service providers to reduce conveyance loss. In some irrigation projects, conveyance loss is more than 40 percent of the total amount of water delivered. The most effective incentive is financial autonomy. If the service providers are completely responsible for the project and fee collection, they will try to reduce water losses so that they have more water to sell, as happened in the Yangtze Basin, China (Maass and Anderson, 1978). When the major objective is to reduce water use, a combination of incentives should be used, not just higher water prices. Even if water cannot be metered effectively, other actions can be taken to help reduce overuse of irrigation water, including crop-based water fees.

\section{CONCLUSIONS AND RECOMMENDATIONS}

There is no one easy means to improve water pricing system and cost recovery. However, many countries have greatly improved cost recovery through basic irrigation reforms. The reforms varied with the irrigation system type, management structure, government policies, and institutional arrangements. As competition for water increases in Nyanyadzi, the irrigation sector must manage its water supplies more efficiently. Farmers' response to water pricing system depends on a variety of endogenous (crop mix) and exogenous conditions (water supply, reliability, existing water institutions, prices of other inputs and availability of appropriate technology). Farmers' participation in decision making is also central to the success of irrigation projects in the study area. Thus, effective policy interventions should therefore address these conditions which are important for the success of irrigation projects.

\section{REFERENCES}

[1] Alaerts, G. (2003). Indonesia: Preliminary Assessment of the Impact of the First Phase of Its Irrigation Reform (1999-2002). Jakarta Office, Rural Development and Natural Resources Unit, World Bank.

[2] Ben-Abdelrazzik, H. (2000). Pricing of Irrigation Water in Morocco, World Bank: Washington DC.

[3] Berbel, J. \& Gomez-Limon, J. A. (2000). Multi-criteria Analysis of Derived Water Demand Functions: A Spanish Case Study. Agricultural Systems 63(1):49-72.

[4] Bosworth, B. G., Cornish, C., Perry, C \& van Steenburgen, F. (2002). Water Charging in Irrigated Agriculture: Lessons from the Literature. Wallingford Ltd, Wallingford, UK. 
[5] Cakmak, E. H. (2000). Pricing of Irrigation Water in Turkey, World Bank: Washington DC.

[6] Coward, E.W. (1980). Irrigation and Agricultural Development in Asia. New York: Cornell University Press.

[7] Chifamba, E. (2011). Adoption and Mitigation Strategies in Sustainable Land Resources Management to Combat the Effects of Climate Change in Chipinge, Zimbabwe, Journal of Sustainable Development in Africa, 13 (2): 15- 27

[8] Dinar, A. (1998). Water Policy Reforms: Informational Needs and Implementation Obstacles, Water Policy, 3 (1): 367-382.

[9] Dinar, A. (1994). Impact of Energy Cost and Water Resource Availability and Quality on Agriculture and Groundwater Quality in California. Resources and Energy Economics 16 (1): 47-66.

[10] Dinar, A. and Mody, J. (2004). Irrigation water management policies: Allocation and Pricing Principles and Implementation Experience, Natural Resources Forum 28 (2) 112.

[11] Easter, K. W. (1993). Economic Failure Plagues Developing Countries' Public Irrigation: An Assurance Problem. Water Resources Research 29(7): 1913-22.

[12] Gleick, P. H. (1997). Water and Conflict in the Twenty-First Century: The Middle East and California, In D. Parker and Y. Tsur (eds.) Decentralization and Coordination of Water Resource Management, Boston: Kluwer Academic Publishers.

[13] Gleick, P. H. (1992). Effects of Climate Change on Shared Fresh Water Resources, In I.M. Mintzer (ed.), Confronting Climate Change: Risks, Implications and Responses, Cambridge: Cambridge University Press.

[14] Howe, C.W. (1979). Natural Resource Economics. New York: John Wiley and Sons, Inc.

[15] Howe, C.W. (1997). Increasing Efficiency in Water Markets: Examples from the Western United States." In Water Marketing-the Next Generation, ed. T. Anderson and P.J. Hill. London: Rowman \& Littlefield Publishers, Inc.

[16] Johansson, R. C., Tsur, Y., Roe, T. L., Doukkali R. M. \& Dinar A. (2002). Pricing and Allocation of Irrigation Water: A Review of Theory and Practice, Water Policy Bulletin, 4 (1): 173-199.

[17] Johansson R.C., Tsur Y., Roe, T.L., Doukkali R. \& Dinar A. (2003). Pricing Irrigation Water: A Review of Theory and Practice. Water Policy, 4 (1): 173-199.

[18] Jones, W. I. (1995). The World Bank and Irrigation. Operations Evaluation Study, World Bank, Washington, D.C.

[19] Lemos, M.C. \& Oliveira, J.L.F. (2004). Can Water Reform Survive Politics? Institutional Change and River Basin Management in Ceara, Northeast Brazil. World Development 32 (12): 13-21.

[20] Maass, A. \& Anderson, R.L. (1978). ...And the Desert Shall Rejoice Conflict, Growth, and Justice in Arid Environments. Cambridge: MIT Press.

[21] Naik, G. \& Kalro, A. H. (2000). A Methodology for Assessing Impact of Irrigation Management Transfer from Farmers' Perspective. Water Policy 2 (1): 123 - 134.

[22] Prato, T. (1998). Natural Resource and Environmental Economics. Ames: lowa State University Press.

[23] Postel, S. (1999). Pillars of Sand: Can the Irrigation Miracle Last? New York: W.W. Norton and Company.

[24] Schur, M. (2000). Pricing of Irrigation Water in South Africa, World Bank: Washington DC.

[25] Tsur, Y. (2000). Water Regulation via Pricing: The Role of Asymmetric Information, In Dinar, A. (ed.). The Political Economy of Water Pricing Reforms, New York: Oxford University Press

[26] Tsur, Y. \& Dinar A. (1997). On the Relative Efficiency of Alternative Methods for Pricing Irrigation Water and Their Implementation, World Bank Economic Review, 11 (1): 243-262. 
[27] Tsur, Y. \& Dinar A. (1997). Efficiency and Equity Considerations in Pricing and Allocating Irrigation Water, World Bank, Washington DC.

[28] Tsur, Y. and Dinar, A. (1998). On The Relative Efficiency of Alternative Methods for Pricing Irrigation Water and Their Implementation. World Bank Economic Review 11 (1): 342351.

[29] World Bank. (1995). Morocco Water Sector Review. Washington, D.C.:World Bank.

[30] Young, H.P. (1985). Cost Allocation: Methods, Principles, Applications. Amsterdam :North-Holland Elsevier Science.

[31] Young, H.P., Okada, N., \& Hashimoto, T. (1982). Cost Allocation in Water Resource Development, Water Resource Research Vol.18.(3) 156 - 167.

[32] Zhang, L., Liu, J. and Hu, D. (2003). The Benefit and Problems of Water User Associations, Issues of Agriculture Economics Vol.2 (1): 456 - 465. 